\title{
Electron Transfer between the Gram-positive Enterococcus faecalis Bacterium and Electrode Surface through Osmium Redox Polymers
}

Pankratova, Galina; Szypulska, Ewelina; Pankratov, Dmitry; Leech, Dónal; Gorton, Lo

Published in:

ChemElectroChem

Link to article, DOI:

$10.1002 /$ celc. 201800683

Publication date:

2019

Document Version

Peer reviewed version

Link back to DTU Orbit

Citation (APA):

Pankratova, G., Szypulska, E., Pankratov, D., Leech, D., \& Gorton, L. (2019). Electron Transfer between the Gram-positive Enterococcus faecalis Bacterium and Electrode Surface through Osmium Redox Polymers. ChemElectroChem, 6(1), 110-113. https://doi.org/10.1002/celc.201800683

\section{General rights}

Copyright and moral rights for the publications made accessible in the public portal are retained by the authors and/or other copyright owners and it is a condition of accessing publications that users recognise and abide by the legal requirements associated with these rights.

- Users may download and print one copy of any publication from the public portal for the purpose of private study or research.

- You may not further distribute the material or use it for any profit-making activity or commercial gain

- You may freely distribute the URL identifying the publication in the public portal 


\section{FUNDAMENTALS \& APPLICATIONS \\ CHEMELECTROCHEM}

ANALYSIS \& CATALYSIS, BIO \& NANO, ENERGY \& MORE

\section{Accepted Article}

Title: Electron Transfer between the Gram-positive Enterococcus faecalis Bacterium and Electrode Surface via Osmium Redox Polymers

Authors: Galina Pankratova, Ewelina Szypulska, Dmitry Pankratov, Dónal Leech, and Lo Gorton

This manuscript has been accepted after peer review and appears as an Accepted Article online prior to editing, proofing, and formal publication of the final Version of Record (VoR). This work is currently citable by using the Digital Object Identifier (DOI) given below. The VoR will be published online in Early View as soon as possible and may be different to this Accepted Article as a result of editing. Readers should obtain the VoR from the journal website shown below when it is published to ensure accuracy of information. The authors are responsible for the content of this Accepted Article.

To be cited as: ChemElectroChem 10.1002/celc.201800683

Link to VoR: http://dx.doi.org/10.1002/celc.201800683 


\title{
Electron Transfer between the Gram-positive Enterococcus faecalis Bacterium and Electrode Surface via Osmium Redox Polymers
}

\author{
Galina Pankratova, ${ }^{*[\mathrm{a}]}$ Ewelina Szypulska ${ }^{[\mathrm{b}]}$ Dmitry Pankratov, ${ }^{[\mathrm{c}]}$ Dónal Leech, ${ }^{[\mathrm{d}]}$ and Lo Gorton* ${ }^{[\mathrm{a}]}$
}

\begin{abstract}
The interaction between microorganisms, that contain thick cell walls such as the Gram-positive bacterium Enterococcus faecalis, and conductive surfaces can be improved using redox polymers as mediators. Here we report on a detailed electrochemical characterization of the communication between E. faecalis cells and a series of osmium redox polymers with different redox potentials. The current generated from glucose oxidation by films containing osmium redox polymers and $E$. faecalis cells increase over time $(28 \mathrm{~h})$ due to a decrease in charge transfer resistance within the films, possibly due to improved penetration of the redox polymer within the bacterial cell wall.
\end{abstract}

Over the past several decades microbial electrochemistry has emerged as a hot research topic in environmental engineering technologies, microbial ecology and microbial physiology. ${ }^{[1]}$ The considerable attention to various electrochemically active microorganisms has been due to potential biotechnological applications, both current producing and current consuming, arising from the possibility of connecting cell metabolism to an electrode. Research on microbial electron exchange reactions associated with solid materials can also provide for a better understanding of biogeochemical cycles and cell-to-cell electrical communication. ${ }^{[2,3]}$

Microbe-electrode interconnection is driven by a microbial metabolic process, known as extracellular electron transfer (EET). Achieving efficient electrochemical interaction between a certain microbial cell and a conductive surface, quantitatively described as the ET rate, is a challenging complex task dependent on a number of factors. ${ }^{[3]}$ There are a few known approaches to enhance EET rates at the cell-electrode interface through promoting direct or mediated ET. ${ }^{[4]}$ Direct ET ensures a minimized overpotential and coulombic losses in combination with a simplified operational design. Gram-positive bacteria and yeasts have a thick cell wall that impair the capacity for effective direct ET; to improve the interaction with the extracellular environment for those microorganisms utilization of artificial mediating agents is required. Use of osmium (Os) redox

[a] G. Pankratova, Prof. L. Gorton

Department of Biochemistry and Structural Biology, Lund University P.O. Box 124, SE-22100 Lund, Sweden

E-mail: galina.pankratova@biochemistry.lu.se; lo.gorton@biochemistry.lu.se

[b] E. Szypulska

Department of Chemistry, University of Warsaw

Pasteura 1, 02-093 Warsaw, Poland

[c] Dr. D. Pankratov

Department of Chemistry, Technical University of Denmark DK-2800 Kongens Lyngby, Denmark

[d] Prof. D. Leech

School of Chemistry and Ryan Institute,

National University of Ireland Galway,

University Road, Galway, Ireland

Supporting information for this article is given via a link at the end of the document.((Please delete this text if not appropriate)) polymers (RPs) has a number of advantages over use of soluble freely diffusing mediators. These include formation of a high local concentration of a redox network, a stable multilayered 3Dhydrogel serving as a matrix for further "wiring" biocatalysts, and simplified design of constructed systems in contrast to use of diffusing mediators. ${ }^{[5]}$ Originally Os-based electron-conducting polymers were demonstrated as mediators facilitating ET between redox enzymes and electrodes. ${ }^{[6]}$ The very first "wired" using an Os RP matrix was bacterium Gluconobacter oxydans as reported in $2004 .{ }^{[7]}$ Since that time several bacteria, both Gram-negative ${ }^{[8]}$ and Gram-positive ${ }^{[9]}$ have been electrochemically connected to various electrode materials via Os-based mediators. Among others, the Gram positive bacterium Enterococcus faecalis has recently been demonstrated to perform EET to gold electrodes mediated by a Os-based polymeric shuttle. ${ }^{[9 b]}$ In the current work we continue our investigation on the electrochemical communication between $E$. faecalis cells and Os-based polymeric mediators and report, to the best of our knowledge, the very first detailed characterization of ET in the system Gram-positive bacteriumOs RP-electrode.

Herein we have tested three different Os RP as mediators: [Os (4,4'-dimethyl-2,2'-bipyridine $)_{2}$ (poly-vinylimidazole $\left.{ }_{10} \mathrm{Cl}\right]^{+/ 2+}$ $(\mathrm{Os}-1),{ }^{[10]}\left[\mathrm{Os}\left(2,2^{2} \text {-bipyridine }\right)_{2}\right.$ (poly-vinylimidazole) ${ }_{10} \mathrm{Cl}^{+/ 2+}$ (Os2), ${ }^{[11]} \quad$ Os $\left(4,4\right.$ '-dicholo-2,2'-bipyridine) ${ }_{2}$ (polyvinylimidazole $\left.{ }_{10} \mathrm{Cl}\right]^{+/ 2+}$ (Os-3). ${ }^{[12]}$ The Os RPs have analogous chemical structures, but with various ligands coordinating the redox center of the polymers and thus varying redox potentials, $E^{0}$, in the range from 0.320 to $0.490 \mathrm{~V}$ (Table 1 ). The $E^{0 \text {, values }}$ were estimated by taking the mean value of the anodic and cathodic peak potentials of the recorded cyclic voltammograms (CVs) (Figure S1). Note, that all potential values in this work are reported versus the standard hydrogen electrode (SHE).

To prepare Os RP modified electrodes a $5 \mu \mathrm{L}$ aliquot of an aqueous polymer solution $\left(10 \mathrm{mg} \mathrm{mL}^{-1}\right)$ was dropcast on a polished graphite rod (Alfa Aesar $\mathrm{GmbH}$, Germany, $\varnothing 3.05 \mathrm{~mm}$ ) surface and dried at room temperature for $30 \mathrm{~min}$. In the case of microbial modification of the electrodes an additional layer of 1 $\mu \mathrm{L}$ of an $E$. faecalis cell suspension ( $1 \mathrm{~g} \mathrm{~mL}^{-1}$, wet weight) was applied on the top of the Os RP modified electrodes and dried again for $10 \mathrm{~min}$. In order to prevent the leakage of the applied material all electrodes were covered with a dialysis membrane presoaked in buffer (Spectrum Laboratories Inc., USA, 6000$8000 \mathrm{Da}$ cutoff). All experiments were performed in a $50 \mathrm{mM}$ phosphate buffer containing $0.1 \mathrm{M} \mathrm{KCl}(\mathrm{pH} 7.40)$. For a detailed description of the experimental procedures, see the Supporting Information (SI).

The electrochemical behavior of the Os RP modified electrodes was characterized by $\mathrm{CV}$. The $\mathrm{CV}$ s recorded at different scan rates $\left(v, 0.0005\right.$ to $\left.1.0 \mathrm{~V} \mathrm{~s}^{-1}\right)$ display a well-defined pair of oxidation and reduction peaks (Figure S1). The quantity of redox active Os on the electrode surface was calculated from CVs by integration of the area under the redox peak; the surface 
coverage, $\Gamma$, values are presented in Table 1. Since diffusioncontrolled processes are significant in ET of the Os RPs, ${ }^{[13]}$ the Nicholson method ${ }^{[14]}$ was applied to estimate apparent ET rate constants, $k_{\text {app }}$ (Figure S2), cognisant that uncompensated resistance can influence this estimate. More details can be found in the SI. The estimated $k_{\text {app }}$ value (Table 1 ) is highest for the Os-1 modified electrodes even though the Os-1 polymer has the lowest $E^{0,}$ in the selection, $0.33 \mathrm{~V}$. Os- 1 polymer was not however the best in accepting electrons from the $E$. faecalis cells among the others. Background subtracted anodic waves of CVs for the bacterial cells mediated by the various Os RPs in response to D-glucose are shown in Figure 1a. They were obtained as the difference between the anodic waves recorded in $10 \mathrm{mM}$ D-glucose and buffer solution. Control CV experiments for the Os RP modified electrodes in the absence/presence of Dglucose were performed (Figure 1a, dashed curves). Very little current response (about 1-2 $\mu \mathrm{A} \mathrm{cm}^{-2}$ ) was observed from the Os RPs, which indicates the almost total absence of parasitic current input from the used Os mediators. When the cells were applied, well-pronounced bioelectrocatalytic currents occured for all the Os RP modified electrodes at a potential higher than 0.2 $\mathrm{V}$ (Figure 1a). The highest current generation $\left(51 \pm 2 \mu \mathrm{A} \mathrm{cm}{ }^{-2}\right.$ at $0.6 \mathrm{~V}$ ) was observed with Os-2, which had the marginally lowest estimated ET rate constant with the electrode. This polymer also displayed the best results in terms of generated current output for all the biocatalysts tested using the same mediator selection, viz. algae,${ }^{[15]}$ cyanobacteria ${ }^{[16]}$ purple nonsulfur bacterium, ${ }^{[17]}$ thylakoid membranes, ${ }^{[18]}$ and glucose dehydrogenase. ${ }^{[19]}$ The lowest current density was registered for the Os-3 polymer even though it has the highest $E^{0}$, value. Such an affect could be attributed to a decreased $\Gamma$ of the electrode by the polymer (Table 1) and thus, less active electrochemical mediator capacity.
D-glucose. The applied potential value was chosen to ensure a potential-independent response for all the patterns. Furthermore, maximum current generation by the cells was observed for all the Os RP modified electrodes at this particular potential (Figure 1a). The Nyquist plots of the experimental data were fitted by employing an equivalent circuit model presented in Figure 2a (inset), which has successfully been applied for the characterization of conducting polymer-modified electrodes ${ }^{[20]}$ as well as for the electrochemical behavior of Gram-positive bacteria. ${ }^{[21]}$ In the proposed circuit, $R_{S}$ is the ohmic solution resistance, $R_{p}$ represents the polarization resistance, the charge transfer resistance is given by $R_{c t}$, the effect from the non-ideal double layer electrode capacitance and pseudocapacitance is represented by the two constant phase elements, $C P E_{d l}$ and $C P E_{\varphi}$, respectively. The accuracy of the fitting in respect to the experimental data is confirmed by a satisfactory approximation, $\chi^{2}$, which was about $10^{-4}$ for all data fittings (Table S1). The monitored $R_{c t}$ values, indirect evaluation of the ET reaction rate, are listed in Table 1. As can be seen from the EIS data fitting,

\section{a}

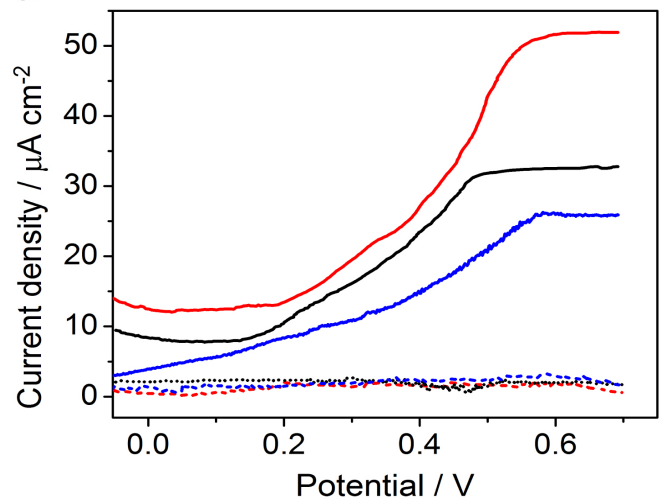

b

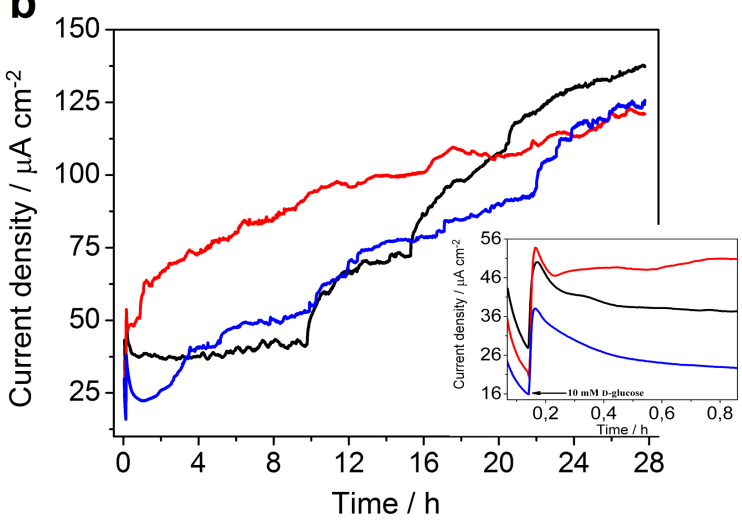

Figure 1. Electrochemical communication between $E$. faecalis cells and graphite electrode surface mediated by Os-1 (black), Os-2 (red) and Os-3 (blue) in the presence of $10 \mathrm{mM}$ D-glucose: (a) Background subtracted anodic cyclic voltammetric waves obtained as a difference between anodic waves recorded in buffer with and without $10 \mathrm{mM}$ D-glucose (solid curves). Dashed curves show catalytic current generated by Os RPs in the presence of $10 \mathrm{mM}$ D-glucose. Scan rate $0.5 \mathrm{mV} \mathrm{s}^{-1}$; (b) Long-term amperometry measurements at constantly applied potential of $0.6 \mathrm{~V}$. The inset shows the initial period of the amperometric measurements when D-glucose has just been added. All potentials are given vs. SHE. 
the best ET was achieved for Os-2 with the lowest $R_{c t}$ of $5.53 \pm 0.51 \mathrm{k} \Omega$, which may explain the highest current response from the $E$. faecalis cells when employing it as a mediator compared to the other Os RP. The obtained $R_{c t}$ magnitude is in complete agreement with the current-generating trend (Figure 1a) of bacterial cells mediated by different Os polymers. However, $R_{c t}$ values for the system bacterial cell-Os polymerelectrode do not correlate with the $k_{a p p}$ values within the polymeric matrix. This suggests that the electrochemical communication between the microbial cells and the Os RPs is limited by the ET rate between the E. faecalis cells and the Osbased mediators, but not by the ET at the electrode-Os RP interface.

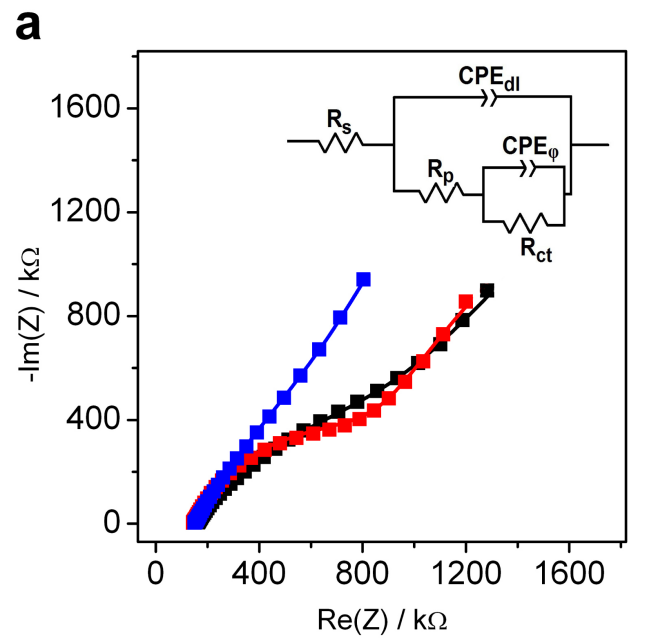

b

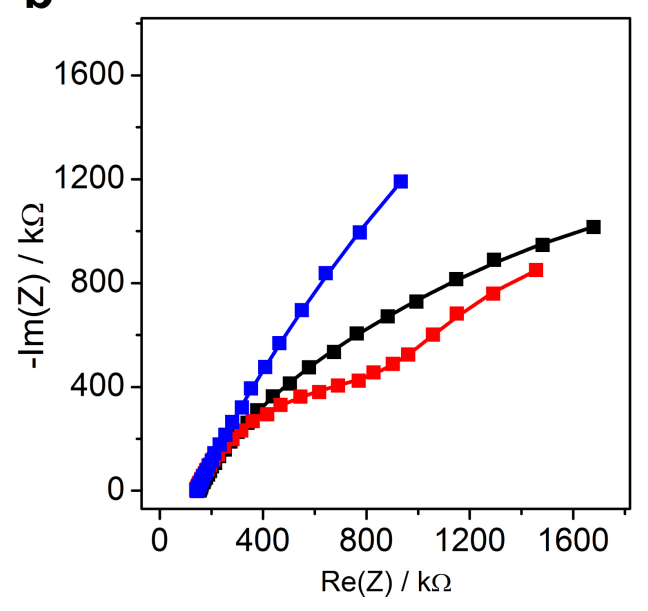

Figure 2. Representative Nyquist plots of E. faecalis-Os RP (Os-1 (black) Os-2 (red) and Os-3 (blue)) interaction obtained at $0.6 \mathrm{~V}$ vs. SHE in the precence of $10 \mathrm{mM}$ D-glucose (a) immediately after fabrication of the electrodes and (b) after the long-term amperometric measurements. The solid lines represent the equivalent circuit fitting, whereas the points represent the experimental data. The inset shows the equivalent circuit model used in the fitting, representing electrolyte resistance $\left(R_{s}\right)$, charge transfer resistance $\left(R_{c t}\right)$, polarization resistance $\left(R_{p}\right)$, pseudocapacitance and non-ideal double layer, introduced by two constant phase elements $\left(C P E_{d l}\right.$ and $C P E_{\varphi}$, respectively).
Long-term amperometric measurements of the bacterial cells mediated by the various Os RPs were carried out at a constant potential of $0.6 \mathrm{~V}$ in the presence of $10 \mathrm{mM}$ D-glucose (Figure $2 b)$. In response to the provided electron donor the immobilized E. faecalis cells initiate biocatalytic current generation of various intensity for the used mediators (Figure $2 b$, inset). The general trend of the current-producing dependence on the structure of the employed Os RP was in good agreement with the obtained CV and EIS results, as well as with the previously reported amperometric investigations for biocatalysts of different nature. ${ }^{[16-18]}$ During the first hours of the experiments a decrease in current response to different extent for the Os RPs is observed (Figure 2b). This might be related to the bacteria's adaptation to the new environment. Nevertheless, within the next few hours, a clear continuous current gain with intensity in accordance with the order of the reported $R_{c t}$ values for the studied variations was observed. Bacterial cells mediated by Os2 produced the highest current density. However, after about 19 to $21 \mathrm{~h}$ the order is inverted to conform with the $k_{\text {app }}$ reported trend for the Os RP. To gain insight into the complex situation, additional electrochemical characterization of the modified electrodes was performed by EIS measurements under the same condition as before immediately after the long-term amperometry tests (Figure $2 \mathrm{~b}$ ). After $28 \mathrm{~h}$ of amperometry, the $R_{c t}$ values significantly decreased compared to the initial measurements, which explains the enhanced electron transfer and consequently the rising current generation from the bacterial cells over time for all the Os RP. It cannot be attributed to the bacterial growth on the electrode, since the microbes were supplied only with glucose. All enterococci are nutritionally fastidious and require a complex medium, containing amino acids and vitamins. ${ }^{[22]}$ The fact that the values scale with $k_{a p p}$ for Os RPs could indicate that the efficiency of ET from E. faecalis cells to graphite is now limited by the ET rate of conducting electrons from the Os RP to the electrode, but not by the microbe-mediator interaction. The change in the ET limiting processes might derive from the Os RP ability to penetrate into the bacterial cell over time. The difference in ET efficiency for the Os RPs might also be related to a different penetration ability of the redox polymeric mediators due to their structure.

In conclusion, mediated microbe-electrode interaction is a complex phenomenon. For this reason complementary interdisciplinary research is required to understand the main features of microbial EET nature. Results presented in this study provide an electrochemical description of the E. faecalis cellsOs RP-electrode surface system. The initial electrochemical communication is limited by the interaction between the cells and the Os-based mediators. With time the system performance overcomes the limitation and becomes defined by the ET rates between the Os polymers and the electrode. Taking into consideration all the data, we assume that the penetration of the Os RPs into the bacterial cell wall over time is one of the possible explanations. Electroactive Gram-positive bacteria are still a "black box" when it comes to the electrode associated biochemical mechanisms. However, we believe that our current findings may contribute to a mechanistic understanding of the EET processes in the future. Further research focusing on the aspects of the EET between Gram-positive E. faecalis bacteria and conductive surfaces is now in progress in the laboratory. 


\section{Acknowledgements}

The authors thank the European Commission (Erasmus Programme+ and "BIOENERGY" FP7-PEOPLE-2013-ITN607793) and the Swedish Research Council (project: 20145908) for financial support. We thank Dr. Peter Ó Conghaile (National University of Ireland Galway) for synthesis of the osmium polymers and Prof. Lars Hederstedt (Lund University) for comments on the manuscript.

Keywords: Gram-positive bacterium - Enterococcus faecalis • osmium redox polymers electrochemical communication $•$ extracellular electron transfer

[1] S. Kato, Microbes Environ. 2015, 30, 133-139.

[2] a) D. K. Lovley, ISME J. 2017, 11, 327-336; b) A. Kumar, L. H.-H. Hsu, P. Kavanagh, F. Barrière, P. N. L. Lens, L. Lapinsonnière, J. H. Lienhard, U. Schröder, X. Jiang, D. Leech, Nat. Rev. Chem. 2017, 1, 1-13.

[3] M. A. Rosenbaum, A. E. Franks, Appl. Microbiol. Biotechnol. 2014, 98, 509-518.

[4] a) G. Pankratova, L. Gorton, Curr. Opin. Electrochem. 2017, 5, 193202; b) J. Du, C. Catania, G. C. Bazan, ACS Chem Mater. 2014, 26, 686-697.

[5] a) A. Heller, Curr. Opin. Chem. Biol. 2006, 10, 664-672; b) A. Ruff, Curr. Opin. Electrochem. 2017, 5, 66-73.

[6] A. Heller, J. Phys. Chem. 1992, 96, 3579-3587.

[7] I. Vostiar, E. E. Ferapontova, L. Gorton, Electrochem. Commun. 2004, 6, 621-626.

[8] a) S. Alferov, V. Coman, T. Gustavsson, A. Reshetilov, C. von Wachenfeidt, C. Hägerhäll, L. Gorton, Electrochim. Acta 2009, 54, 4979-4984; b) S. Timur, B. Haghighi, J. Tkac, N. Pazarlioglu, A. Telefoncu, L. Gorton, Bioelectrochemistry 2006, 71, 38-45.

[9] a) V. Coman, T. Gustavsson, A. Finkelsteinas, C. von Wachenfeidt, C. Hägerhäll, L. Gorton, J. Am. Chem. Soc. 2009, 131, 16171-16176; b) G. Pankratova, K. Hasan, D. Leech, L. Hederstedt, L. Gorton, Electrochem. Commun. 2017, 75, 56-59.

[10] T. J. Ohara, R. Rajagopalan, A. Heller, Anal. Chem. 1994, 66, 24512457.

[11] E. M. Kober, J. V. Caspar, B. P. Sullivan, T. J. Meyer, Inorg. Chem. 1988, 27, 4587-4598.

[12] P. A. Jenkins, S. Boland, P. Kavanagh, D. Leech, Bioelectrochemistry 2009, 76, 162-168.

[13] K. Gong, Q. Fang, S. Gu, S. F. Y. Li, Y. Yan, Energy Environ. Sci. 2015, 8, 3515-3530.

[14] R. S. Nicholson, Anal. Chem. 1965, 37, 1351-1355.

[15] K. Hasan, E. Çevik, E. Sperling, M. A. Parker, D. Leech, L. Gorton, Adv. Energy Mater. 2015, 5, 1501100.

[16] K. Hasan, H. B. Yildiz, E. Sperling, P. Ó. Conghaile, M. A. Parker, D. Leech, C. Hägerhäll, L. Gorton, Phys. Chem. Chem. Phys. 2014, 16, $24676-$ 24680.

[17] K. Hasan, K. V. R. Reddy, V. Eßmann, K. Górecki, P. Ó. Conghaile, W. Schuhmann, D. Leech, C. Hägerhäll, L. Gorton, Electroanal. 2015, 27, 118127.

[18] H. Hamidi, K. Hasan, S. C. Emik, Y. Dilgin, H.-E. Åkerlund, P.-Å. Albertsson, D. Leech, L. Gorton, ChemSusChem 2015, 8, 990-993.

[19] M. N. Zafar, X. Wang, C. Sygmund, R. Ludwig, D. Leech, L. Gorton, Anal. Chem. 2012, 84, 334-341.

[20] M. R. Abidian, D. C. Martin, Biomaterials 2008, 29, 1273-1283.

[21] a) X. Suo, L. Abdoli, Y. Liu, P. Xia, G. Yang, H. Li, J. Therm. Spray Technol. 2017, 26, 687-694; b) C. Lu, Y. Zheng, Q. Zhong, Plos One 2017, 12, e0174440.

[23] M. N. Byappanahalli, M. B. Nevers, A. Korajkic, Z. R. Staley, V. J. Harwood, Microbiol. Mol. Biol. Rev. 2012, 76, 685-706. 
WILEY-VCH

\section{COMMUNICATION}

Along the microbe-electrode electron exchange pathway:

Electron transfer features of the Gram-posivitive bacterium

Enterococcus faecalis via osmium redox polymers of various structure and redox potentials are characterized in details using electrochemical techniques.

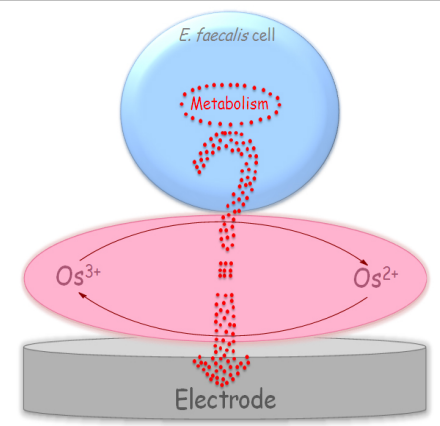

Galina Pankratova, * Ewelina Szypulska, Dmitry Pankratov, Dónal Leech, and Lo Gorton*

Page No. 1 - Page No. 4

Electron Transfer between the Grampositive Enterococcus faecalis Bacterium and Electrode Surface via Osmium Redox Polymers 